DOI https://doi.org/10.30525/978-9934-26-039-1-37

\title{
PSYCHOLOGICAL TERMS OF EMOTIONS IN ENGLISH AND SPANISH: LEXICO-SEMANTIC AND STRUCTURAL PECULIARITIES
}

\author{
Bobchynets L. I. \\ Ph. D. in Romance Languages, \\ Associate Professor at Department of Romance \\ and New Greek Philology and Translation \\ Kyiv National Linguistic University \\ Kyiv, Ukraine
}

Emotions are often discussed in psychological discourse, in research papers, text-books and practical courses of Psychology. Terms of emotions in Psychology reflect concepts of emotions, feelings and emotional states including problematic ones, their symptoms and techniques to improve patients' emotional condition and states. Emotions are usually studied in the courses of General Psychology and Psychology of Emotions, in special courses on anxiety and depression.

The aim of our research is to compare lexico-semantic and structural peculiarities of terms denoting emotions and emotional states in English and Spanish terminology. Methods used in the studies include the analysis of dictionary definitions, lexico-semantic and structural analysis of the mentioned terms.

Emotions are complex notions which may also include emotional states or feelings and can be used as synonyms. Only the context provides correct understanding of the notions. The definition «emotion», provided by APA (American Psychological Association), states: «a complex reaction pattern, involving experiential, behavioral, and physiological elements, by which an individual attempts to deal with a personally significant matter or event. The specific quality of the emotion (e.g., fear, shame) is determined by the specific significance of the event. For example, if the significance involves threat, fear is likely to be generated; if the significance involves disapproval from another, shame is likely to be generated. Emotion typically involves feeling but differs from feeling in having an overt or implicit engagement with the world» [1]. As we may conclude from the definition, emotions and feelings are interrelated and behavior strongly depends on emotional states. As examples of emotions «fear» and «shame are given». The definition of non-specialized dictionary states that «Emotion is a feeling of happiness, love, fear, anger, or hatred, 
which can be caused by the situation that you are in or other people you are with». The synonyms of «emotion» include «feeling, spirit, soul, passion, intuition» [2]. So, it is stated that emotion is a kind of feeling. In Spanish dictionary DRAE emotion is defined as 1) intense and temporary alteration of spirit, pleasant or painful which is accompanied by certain somatic commotion. 2) interest, in general, with expecting character, with which one takes part in the things which occur [3]. The DRAE dictionary emphasizes such qualities of emotions as being pleasant or painful which proves the classification of emotions into negative or positive. According to Diccionario de Psicología (Dictionary of Psychology) by Umberto Galimberti, emotion is defined as intense affective reaction of sharp appearance and short duration, determined by environmental stimuli [5, p. 377]. This definition outlines the quick and short duration of emotion.

Terms of emotions can be classified on the basis of the concepts they express. We propose a lexico-thematic classification of terms of emotions in English and Spanish according to the notions they represent:

1. Nominations of emotions: fear / miedo, anger / ira, shame / vergüenza, happiness / alegría, sadness / tristeza, surprise / sorpresa, etc.

2. Nominations of types of emotions: basic emotions / emociones básicas, secondary emotions / emociones secundarias, social emotions / emociones sociales, instrumental emotions / emociones instrumentales, static emotions / emociones estáticas, etc.

3. Nominations of feelings: love / amor, hatred / odio, affection / apego, etc.

4. Nominations of pathological emotional states: depression / depresión, anxiety / ansiedad, phobia /fobia, etc.

5. Nominations of theories of emotions: physiological theories / teorias fisiológicas, neurological theories / teorías neurológicas, cognitive theories / teorías cognitivas, etc.

6. Nominations of therapeutic techniques of treating pathological states: CBT (cognitive behavior therapy) / terapia cognitiva y de conducta, etc.

As we can see from the definitions and classifications, fears and phobias are synonymic notions. The cause of the synonyms here is the co-existence of national and Greek terminology, such as fear of spiders (arachnophobia) / miedo a arañas (aracnofobia), fear of hight (acrophobia) / miedo a altura (acrofobia), fear of social situations (social phobia) / miedo a situaciones socials (fobia social), fear of animals (zoophobia) / miedo a animals (zoophobia), etc.

Díaz, J. L., Flores, E. O. suggested classification of emotions on the basis of the following principles: «pleasant - unpleasant», for example, pleasure / 
placer - pain / dolor, enthusiasm / entusiasmo - apathy / apatía, «intensive not intensive» or «relajación - excitación» [4]. Terminological glossaries of Psychology and monolingual dictionaries have a bit different definition of emotions, in particular, synonyms, though we can clearly observe that emotions are complex phenomena and it is not always possible to define boundaries between emotions and feelings.

According to the structural analysis, terms of emotions are mainly simple words (fear / miedo), derived words (agarophobia / agarofobia). The main word-formation elements are affixes, in particular, suffixes: anxie-ty / ansie$\mathrm{dad}$. There are also word combinations to specify the term (emotional selfcontrol / autocontrol emocional).

Terms of emotions represent a dynamic terminological system where boundaries between lexical units are not easily defined. Classifications may vary depending on the psychologist and theory. Future studies may be focused on lexicographical factors to help in translation of psychological glossaries and to find ways of unification of terms of emotions in other European languages. English abbreviations in terms of Psychology and their grammar adaptation in Spanish may be the object of our further research.

\section{References:}

1. APA Dictionary. Retrieved from: https://dictionary.apa.org/emotion

2. COBUILD Advanced English Dictionary. Harper Collins Publishers. Retrieved from: https://www.collinsdictionary.com/dictionary/english/emotion

3. Diccionario de Real Academia Española (DRAE). Retrieved from: https://dle.rae.es/emocion

4. Díaz, J.L., Flores, E.O. La estructura de la emoción humana: Un modelo cromático del sistema afectivo. Retrieved from: https://www.medigraphic.com/cgi-

bin/new/resumen.cgi?IDARTICULO=22416

5. Galimberti, Umberto. Diccionario de Psicología. 1236 p. México, Argentina: Siglo XXI Editores. Primera edición en español: 2002. 1236 p. 